\title{
ESTIMATION OF INTERNATIONAL TAX PLANNING IMPACT ON CORPORATE TAX GAP IN THE CZECH REPUBLIC
}

\author{
Lukáš Moravec, Jan Rohan, Jana Hinke
}

\section{Introduction}

The issue of base erosion and profit shifting (BEPS) caused by multinational companies is a potential important impediment to tax collections. Because tax planning schemes utilized gaps and mismatches in tax rules to artificially shift profits to low or no-tax jurisdiction where there is insufficient of no economic activity (Hines, 2014; OECD, 2017). The Organization for Economic Co-operation and Development (OECD) has estimated the general annual revenue loss of USD 100 to 240 billion due to the BEPS OECD (2017).

Dharmapala and Riedel (2013) focused on tax motivated income shifting between parent companies and their affiliates. The parent companies have almost $60 \%$ affiliates established in low-tax jurisdictions. It resulted in profit shifting from the high-tax parent companies' jurisdictions to the low-tax affiliates' jurisdictions where the profit is taxed with the lower tax rate. Companies may also benefit from the difference between the statutory and the marginal tax rates that jurisdictions offer. This fact has important role in profit shifting across jurisdictional boundaries (Zodrow, 2010; Lennard, 2016; Baumann, Buchwald, Friehe, Hottenrott, \& Weche, 2017). There are many authors who deal with the issue that multinational companies shift their profits thanks to tax differentials through the use of transfer pricing mechanism, royalties, inter-company transactions, etc. (Altshuler \& Grubert, 2006; 2002; Hines, 1999; Desai, Foley, \& Hines, 2004; 2006). This is not the only purpose of preferential tax jurisdiction. Companies also invest in tax havens because of the secrecy these jurisdictions offer (Braun \& Weichenrieder, 2015). The number of Czech companies, whose owners are established in tax havens, have decreased approximately by $43 \%$ after conclusion of instruments for exchange of tax information with these jurisdictions. This indicates the importance of anonymity. On the other hand, companies that remain in the jurisdictions after conclusion of such instruments increase investments due to better tax conditions (Rohan \& Moravec, 2017).

Currently, there are four studies made by international organizations that are focused on the estimation of the international corporate tax avoidance caused by base erosion and profit shifting: International Monetary Fund (IMF) (2014), OECD (2015), United Nations Conference on Trade and Development (UNCTAD) (2015), European Parliament Research Service (EPRS) (2015). There are also other authors who deal with the corporate income tax gap (e.g. Cobham \& Jansky, 2017; Davies et al., 2015; Gumpert, Hines, \& Schnitzer, 2016; Riedel, Zinn, \& Hofmann, 2015; Crivelli, de Mooij \& Keen, 2016). Jansky (2016) and Jansky and Kokes (2016) define the tax gap as the difference between the real amount of tax legally due and the amount that taxpayers actually pay.

This paper focuses on the calculation of corporate income tax efficiency indicator and its comparison with other EU member states. Furthermore, the paper is aimed at the estimative amount of corporate income tax revenue that the Czech Republic might have lost as a result of international corporate tax avoidance in 2013, 2014 and 2015 and subsequently this paper shows variety and differences among different studies as the presented estimation is made with official data obtained from General Financial Directorate instead from Eurostat and there the main reason for different results can be seen. The estimation combines the European Parliament Research Service's (2015) methodology and the IMF (2014) approach. 


\section{Materials and Methods}

The corporate tax gap revenue estimation uses IMF (2014) and EPRS (2015) methodology. The methodology has been chosen for comparison's purposes. EPRS (2015) research uses Eurostat data compared to this paper, which uses official data from General Financial Directorate. Moreover the used methodology seems to be more precise in comparison with the methodology used for example by Glopolis (2016). This methodology estimates the tax gap's impact through indicators mentioned below. The other methodology calculates the impact from total amount of EU corporate tax gap through ration of particular member states' contributions to EU Gross Domestic Product. The methodology calculates the corporate income tax efficiency weighted average for all 28 European Union (EU) member states (MS) and net operating surplus adjusted for imputed compensation of self-employed as a theoretical corporate income tax base. These indicators are necessary for subsequent calculation of the revenue without profit shifting. Ebrill and others (2001) use a similar concept of tax efficiency to assess the performance of Value added tax. The analyzed data was obtained from the General Financial Directorate, AMECO, Eurostat and European Commission. The corporate tax revenue loss/gain is calculated for three periods: 2013, 2014 and 2015. EPRS (2015) study ends with the year 2013. One of the aims of this paper is to compare the results with EPRS (2015) study for 2013 and to continue with tax gap's estimation for upcoming years. Therefore, the year 2013 was set as a default time-period. The observation period ends in 2015 because there was no updated data during the research preparation. The first research question is - how the corporate income tax revenues of the Czech Republic are influenced by base erosion and profit shifting. The second research question is how effective the corporate income tax system of the Czech Republic is and the third one how the difference in datasource influences the corporate tax gap estimation.

Based on the research questions null hypotheses have been established as follow:

- $H_{01}$ : Base erosion and profit shifting do not cause a corporate income tax loss in the Czech Republic.

- $H_{02}$ : The corporate income tax efficiency indicator of the Czech Republic is lower than EU average in the mentioned time period.

- $H_{03}$ : Difference in data source does not influence final results of the corporate income tax gap estimation.

\subsection{Corporate Income Tax Efficiency}

To begin with, an indicator of corporate income tax efficiency has been constructed. The indicator comes from IMF's report on spillovers:

$$
\operatorname{Eff}_{i}=\frac{\text { Rev }_{i}}{\left(\text { Rate }_{i} \div 100\right) \times \text { Base }_{1}}
$$

The corporate income tax efficiency for

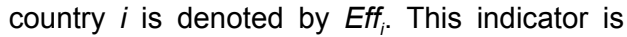
calculated for particular EU member states. This step is required for second equation. $R e v_{i}$ represents actual corporate income tax revenue of country $i$ in a local currency. The data of corporate income tax revenue for the Czech Republic comes from General Financial Directorate. For the rest of EU MSs, it comes from public finance and national accounts data from Eurostat. Rate ${ }_{i}$ represents the statutory corporate income tax rate that is applied in the state $i$. The percentage tax rate is divided by 100 . The data source of corporate income tax rate is used from European Commission's publications on taxation trends in the EU. Base ${ }_{i}$ denotes the theoretical tax base of country $i$. There are available three types of operating surplus, which could be used as the theoretical tax base. Gross operating surplus, net operating surplus not adjusted for imputed compensation for self-employed workers, who are being treated for tax purposes as being external contractors and there are are not subject of income taxes from employment, pension etc. and the last one net operating surplus adjusted for imputed compensation for self-employed workers. The paper deals with the taxes on the corporate income excluding income of self-employed persons, whose surplus above their costs is taxed as personal income than corporate profit. Therefore the theoretical tax base is expressed by the net operating surplus adjusted for imputed compensation for selfemployed workers. AMECO is used as the data source of the theoretical tax base. According to the EPRS's study, if the Eff takes the value further below one, the corporate income tax system is the less efficient in acquiring revenue. This may indicate tax competition (e.g. tax 


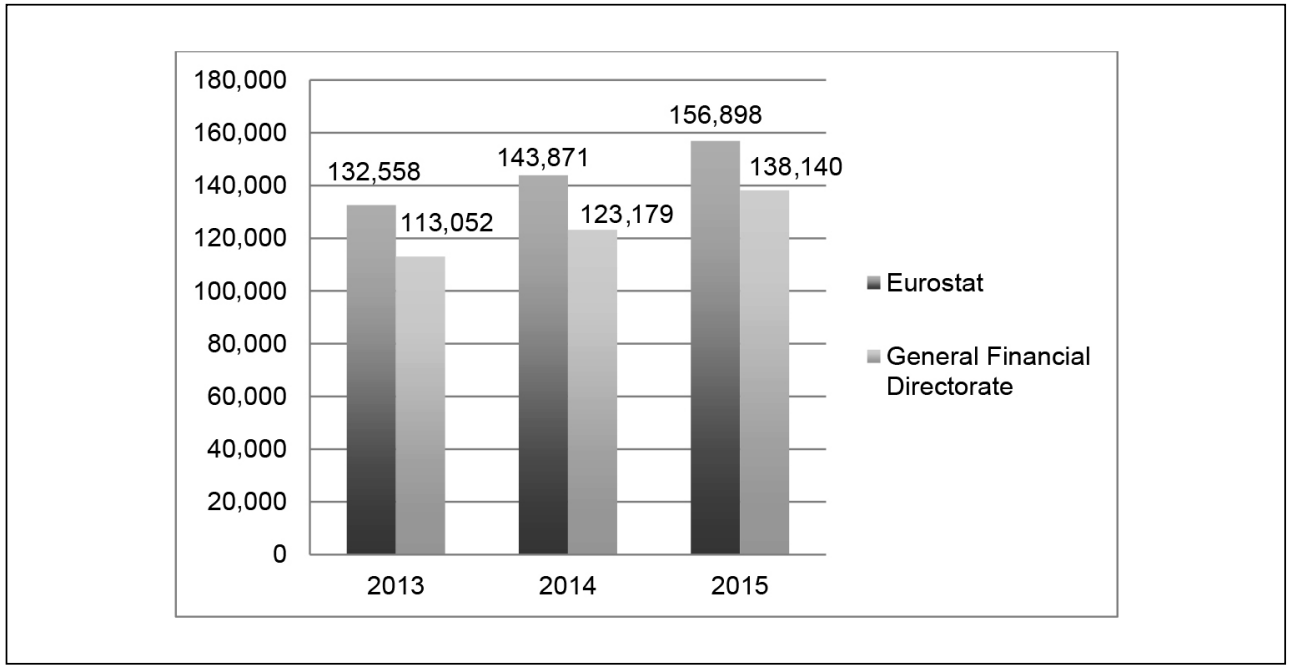

Source: own processing in accordance with Eurostat, General Financial Directorate

incentives) but also the profit shifting. The difference between the corporate tax revenue data sources can be seen below. EPRS uses Eurostat database for its calculation. In this research the official data from Czech General Financial Directorate has been used.

Hereinafter the calculation of the corporate income tax efficiency for particular EU member states for time period 2013 is described. The efficiency is needed for the subsequent indicator of revenue without profit shifting estimation. Moreover the results confirm possible differences of research outputs due to the different data sets.

Tab. 2 contains the calculation of the corporate income tax efficiency for particular EU member states for time period 2014.

Tab. 3 below deals with the calculation of the corporate income tax efficiency for particular EU member states for time period 2015.

\subsection{Indicator of Revenue without Profit Shifting}

The second indicator gives an overview of how much the Czech Republic loses/gains from profit shifting. The indicator represents a hypothetical value of tax revenues that the jurisdiction could have received in case there is not any profit shifting applied:

$$
\mathrm{RWS}_{i}=\left(\text { Rate }_{i} \div \text { 100) } \times \text { Base }_{i} \times \overline{E f f}_{i}\right.
$$

The tax revenue without profit shifting is denoted by $\boldsymbol{R} \boldsymbol{W} \boldsymbol{S}_{i}$. Rate $_{i}$ represents the statutory corporate income tax rate that is applied in the state $i$. The percentage tax rate is divided by 100 . The data source of corporate income tax rate is used from European Commission's publications on taxation trends in the EU. Base in $_{i}$ denotes the theoretical tax base of country $i$. The theoretical tax base is expressed by the net operating surplus adjusted for imputed compensation for self-employed workers. AMECO is used as the data source of the theoretical tax base. $\overline{\boldsymbol{E f f}}_{i}$ is the weighted average of corporate income tax efficiency rate for the entire EU. This variable enables to exclude base effects except profit shifting.

The final effect is given by the difference between revenue without profit shifting $\left(\boldsymbol{R} \boldsymbol{W} \boldsymbol{S}_{i}\right)$ and the actual corporate income tax revenue denoted by $\boldsymbol{R e v}_{i}$. The difference can be interpreted as the loss or gain from profit shifting. In the case the actual corporate income tax revenue takes a higher value than the revenue without profit shifting indicator then the jurisdiction profits from the profit shifting. The opposite situation results in tax revenue losses caused by profit shifting. 


\begin{tabular}{|c|c|c|c|c|c|c|}
\hline $\begin{array}{ll}\text { Tab. 1: } & \text { Calc } \\
\text { stat }\end{array}$ & $\begin{array}{l}\text { tion of } \\
\text { or tim }\end{array}$ & $\begin{array}{l}\text { e corpor } \\
\text { eriod } 20\end{array}$ & $\begin{array}{l}\text { incom } \\
\text { (Part 1) }\end{array}$ & ax effici & for particular & nber \\
\hline Country & Unit & Base (bn) & $\begin{array}{l}\text { Tax rate } \\
\text { (\%) }\end{array}$ & $\begin{array}{l}\text { Revenues } \\
\text { (bn) }\end{array}$ & Eff calculation & Eff \\
\hline Belgium & EURO & 34.23612 & 33.99 & 12.2091 & $\frac{12.2091}{0.3399 \times 34.23612}$ & 1.049175 \\
\hline Bulgaria & BGN & 16.57857 & 10 & 1.6231 & $\frac{1.6231}{0.1 \times 1.6231}$ & 0.979035 \\
\hline Czech Republic & CZK & 807.735 & 19 & 113.052 & $\frac{113.052}{0.19 \times 807.735}$ & 0.736641 \\
\hline Denmark & DKK & 239.6818 & 25 & 54.066 & $\frac{54.066}{0.25 \times 239.6818}$ & 0.902296 \\
\hline Germany & EURO & 445.6341 & 29.55 & 50.5 & $\frac{50.5}{0.2955 \times 445.6341}$ & 0.383491 \\
\hline Estonia & EURO & 4.315953 & 21 & 0.0618 & $\frac{0.0168}{0.21 \times 4.315953}$ & 0.068186 \\
\hline Ireland & EURO & 49.1836 & 12.5 & 4.272 & $\frac{4.272}{0.125 \times 4.272}$ & 0.694866 \\
\hline Greece & EURO & 34.82386 & 26 & 2.071 & $\frac{2.071}{0.26 \times 34.82386}$ & 0.228734 \\
\hline France & EURO & 196.7501 & 33.33 & 58.736 & $\frac{58.736}{0.3333 \times 196.7501}$ & 0.895683 \\
\hline Croatia & HRK & 32.8425 & 20 & 6.7418 & $\frac{6.7418}{0.20 \times 32.8425}$ & 1.026383 \\
\hline Italy & EURO & 174.3434 & 31.4 & 40.3767 & $\frac{40.3767}{0.314 \times 174.3434}$ & 0.737557 \\
\hline Cyprus & EURO & 4.049885 & 12.5 & 1.1714 & $\frac{1.1714}{0.125 \times 4.049885}$ & 2.313942 \\
\hline Latvia & EURO & 4.20113 & 15 & 0.3697 & $\frac{0.3697}{0.15 \times 4.20113}$ & 0.586668 \\
\hline Lithuania & EURO & 11.32114 & 15 & 0.4767 & $\frac{0.4767}{0.15 \times 11.32114}$ & 0.280714 \\
\hline Luxembourg & EURO & 10.65323 & 29.22 & 2.2128 & $\frac{2.2128}{0.2922 \times 10.65323}$ & 0.710854 \\
\hline Hungary & HUF & $6,003.473$ & 19 & 416.189 & $\frac{416.189}{0.19 \times 6,003.473}$ & 0.364867 \\
\hline Malta & EURO & 1.809474 & 35 & 0.4212 & $\frac{0.4212}{0.35 \times 1.809474}$ & 0.665071 \\
\hline Netherlands & EURO & 89.4848 & 25 & 14.255 & $\frac{14.255}{0.25 \times 89.4848}$ & 0.637203 \\
\hline Austria & EURO & 45.57368 & 25 & 7.2404 & $\frac{7.2404}{0.25 \times 45.57368}$ & 0.635490 \\
\hline Poland & PLN & 488.7057 & 19 & 29.351 & $\frac{29.351}{0.19 \times 488.7057}$ & 0.316098 \\
\hline Portugal & EURO & 28.37738 & 25 & 5.5446 & $\frac{5.5446}{0.25 \times 28.37738}$ & 0.781552 \\
\hline Romania & RON & 152.5669 & 16 & 12.826 & $\frac{12.826}{0.16 \times 152.5669}$ & 0.525425 \\
\hline
\end{tabular}




\begin{tabular}{|c|c|c|c|c|c|c|}
\hline Tab. 1: & \multicolumn{6}{|c|}{$\begin{array}{l}\text { Calculation of the corporate income tax efficiency for particular EU member } \\
\text { states for time period } 2013 \text { (Part 2) }\end{array}$} \\
\hline Country & Unit & Base (bn) & $\begin{array}{c}\text { Tax rate } \\
(\%)\end{array}$ & $\begin{array}{l}\text { Revenues } \\
\text { (bn) }\end{array}$ & Eff calculation & Eff \\
\hline Slovenia & EURO & 0.816451 & 17 & 0.4332 & $\frac{0.4332}{0.17 \times 0.816451}$ & 3.121112 \\
\hline Slovakia & EURO & 19.6832 & 23 & 2.1178 & $\frac{2.1178}{0.23 \times 19.6832}$ & 0.467801 \\
\hline Finland & EURO & 23.51961 & 24.5 & 4.799 & $\frac{4.799}{0.245 \times 23.51961}$ & 0.832827 \\
\hline Sweden & SEK & 461.493 & 22 & 100.811 & $\frac{100.811}{0.22 \times 461.493}$ & 0.992933 \\
\hline United Kingdom & GBP & 297.2532 & 23 & 41.644 & $\frac{41.644}{0.23 \times 297.2532}$ & 0.609113 \\
\hline
\end{tabular}

Source: authors' own calculation, AMECO, General Financial Directorate, European Commission, Eurostat

\begin{tabular}{|c|c|c|c|c|c|c|}
\hline Tab. 2: & \multicolumn{6}{|c|}{$\begin{array}{l}\text { Calculation of the corporate income tax efficiency for particular EU member } \\
\text { states for time period } 2014 \text { (Part 1) }\end{array}$} \\
\hline Country & Unit & Base (bn) & $\begin{array}{l}\text { Tax rate } \\
(\%)\end{array}$ & $\begin{array}{l}\text { Revenues } \\
\text { (bn) }\end{array}$ & Eff calculation & Eff \\
\hline Belgium & EURO & 38.17151 & 33.99 & 12.8901 & $\frac{12.8901}{0.3399 \times 38.17151}$ & 0.993495 \\
\hline Bulgaria & BGN & 14.64406 & 10 & 1.6582 & $\frac{1.6582}{0.10 \times 14.64406}$ & 1.132336 \\
\hline Czech Republic & CZK & 948.5900 & 19 & 123.179 & $\frac{123.179}{0.19 \times 948.59}$ & 0.683447 \\
\hline Denmark & DKK & 243.5001 & 24.5 & 55.784 & $\frac{55.784}{0.245 \times 243.5001}$ & 0.935071 \\
\hline Germany & EURO & 461.7875 & 29.58 & 51 & $\frac{51.0}{0.2958 \times 29.58}$ & 0.373362 \\
\hline Estonia & EURO & 4.29285 & 21 & 0.0689 & $\frac{0.0689}{0.21 \times 4.29285}$ & 0.076428 \\
\hline Ireland & EURO & 54.48542 & 12.5 & 4.6169 & $\frac{4.6169}{0.125 \times 54.48542}$ & 0.677891 \\
\hline Greece & EURO & 32.47029 & 26 & 3.349 & $\frac{3.349}{0.26 \times 32.47029}$ & 0.396694 \\
\hline France & EURO & 201.6106 & 33.33 & 57.063 & $\frac{57.063}{0.3333 \times 201.6106}$ & 0.849192 \\
\hline Croatia & HRK & 38.07952 & 20 & 5.8247 & $\frac{5.8247}{0.20 \times 38.07952}$ & 0.764807 \\
\hline Italy & EURO & 183.1952 & 31.4 & 35.0612 & $\frac{35.0612}{0.314 \times 183.1952}$ & 0.609513 \\
\hline Cyprus & EURO & 3.842498 & 12.5 & 1.1121 & $\frac{1.1121}{0.125 \times 3.842498}$ & 2.315369 \\
\hline Latvia & EURO & 3.856079 & 15 & 0.3637 & $\frac{0.3637}{0.15 \times 3.856079}$ & 0.628791 \\
\hline Lithuania & EURO & 11.40447 & 15 & 0.4998 & $\frac{0.4998}{0.15 \times 11.40447}$ & 0.292166 \\
\hline
\end{tabular}



states for time period 2014 (Part 2)

\begin{tabular}{l|c|c|c|c|c|c}
\multicolumn{1}{c|}{ Country } & Unit & Base (bn) & $\begin{array}{c}\text { Tax rate } \\
(\%)\end{array}$ & $\begin{array}{c}\text { Revenues } \\
\text { (bn) }\end{array}$ & Eff calculation & Eff \\
\hline Luxembourg & EURO & 12.05523 & 29.22 & 2.1398 & $\frac{2.1398}{0.2922 \times 12.05523}$ & 0.607460 \\
\hline Hungary & HUF & $6,845.882$ & 19 & 534.652 & $\frac{534.652}{0.19 \times 6.845 .882}$ & 0.411040 \\
\hline Malta & EURO & 1.871742 & 35 & 0.4475 & $\frac{0.4475}{0.35 \times 1.871742}$ & 0.683092 \\
\hline Netherlands & EURO & 89.1968 & 25 & 17.09 & $\frac{17.09}{0.25 \times 89.1968}$ & 0.766395 \\
\hline Austria & EURO & 45.71002 & 25 & 7.273 & $\frac{7.273}{0.25 \times 45.71002}$ & 0.636447 \\
\hline Poland & PLN & 505.1986 & 19 & 30.04 & $\frac{30.04}{0.19 \times .194986 n}$ & 0.312957 \\
\hline Portugal & EURO & 29.76808 & 23 & 4.8967 & $\frac{4.8967}{0.23 \times 29.76808}$ & 0.715196 \\
\hline Romania & RON & 152.4887 & 16 & 14.1964 & $\frac{14.1964}{0.16 \times 152.4887}$ & 0.581863 \\
\hline Slovenia & EURO & 1.51095 & 17 & 0.5287 & $\frac{0.5287}{0.17 \times 1.51095}$ & 2.058308 \\
\hline Slovakia & EURO & 19.31105 & 22 & 2.5044 & $\frac{2.5044}{0.22 \times .224405 n}$ & 0.589488 \\
\hline Finland & EURO & 24.4328 & 20 & 3.956 & $\frac{3.956}{0.20 \times 24.4328}$ & 0.809567 \\
\hline Sweden & SEK & 509.9859 & 22 & 103.237 & $\frac{103.237}{0.22 \times 509.9859}$ & 0.920141 \\
\hline United Kingdom & GBP & 331.8269 & 21 & 41.264 & $\frac{41.264}{0.21 \times 331.8269}$ & 0.592162 \\
\hline
\end{tabular}

Source: Authors' own calculation, AMECO, General Financial Directorate, European Commission, Eurostat

Tab. 3: Calculation of the corporate income tax efficiency for particular EU member states for time period 2015 (Part 1)

\begin{tabular}{l|c|c|c|c|c|c}
\multicolumn{1}{c|}{ Country } & Unit & Base (bn) & $\begin{array}{c}\text { Tax rate } \\
(\mathbf{\%})\end{array}$ & $\begin{array}{c}\text { Revenues } \\
(\mathbf{b n})\end{array}$ & Eff calculation & Eff \\
\hline Belgium & EURO & 43.48916 & 33.99 & 13.8169 & $\frac{13.8169}{0.3399 \times 43.48916}$ & 0.934713 \\
\hline Bulgaria & BGN & 15.22104 & 10 & 1.8034 & $\frac{1.8034}{0.10 \times 15.22104}$ & 1.184807 \\
\hline Czech Republic & CZK & $1,013.1040$ & 19 & 138.14 & $\frac{138.14}{0.19 \times 1013.104}$ & 0.717649 \\
\hline Denmark & DKK & 229.6731 & 22 & 53.08 & $\frac{53.08}{0.22 \times 229.6731}$ & 1.050500 \\
\hline Germany & EURO & 487.3359 & 29.72 & 52.9 & $\frac{52.9}{0.2972 \times 487.3359}$ & 0.365240 \\
\hline
\end{tabular}




\begin{tabular}{|c|c|c|c|c|c|c|}
\hline Tab. 3: & \multicolumn{6}{|c|}{$\begin{array}{l}\text { Calculation of the corporate income tax efficiency for particular EU member } \\
\text { states for time period } 2015 \text { (Part 2) }\end{array}$} \\
\hline Country & Unit & Base (bn) & $\begin{array}{c}\text { Tax rate } \\
(\%)\end{array}$ & $\begin{array}{l}\text { Revenues } \\
\text { (bn) }\end{array}$ & Eff calculation & Eff \\
\hline Estonia & EURO & 3.59341 & 20 & 0.0381 & $\frac{0.0381}{0.20 \times 3.59341}$ & 0.053014 \\
\hline Ireland & EURO & 80.50267 & 12.5 & 6.8718 & $\frac{6.8718}{0.125 \times 12.50267}$ & 0.682889 \\
\hline Greece & EURO & 31.18964 & 29 & 3.8 & $\frac{3.8}{0.29 \times 31.18964}$ & 0.420122 \\
\hline France & EURO & 216.9506 & 33.33 & 57.699 & $\frac{57.699}{0.3333 \times 216.9506}$ & 0.797943 \\
\hline Croatia & HRK & 38.06926 & 20 & 6.3113 & $\frac{6.3113}{0.20 \times 38.06926}$ & 0.828923 \\
\hline Italy & EURO & 189.0033 & 31.4 & 33.4663 & $\frac{33.4663}{0.314 \times 189.0033}$ & 0.563909 \\
\hline Cyprus & EURO & 3.919699 & 12.5 & 1.0456 & $\frac{1.0456}{0.125 \times 3.919699}$ & 2.134041 \\
\hline Latvia & EURO & 3.43082 & 15 & 0.3886 & $\frac{0.3886}{0.15 \times 3.43082}$ & 0.755116 \\
\hline Lithuania & EURO & 10.67051 & 15 & 0.5739 & $\frac{0.5739}{0.15 \times 10.67051}$ & 0.358558 \\
\hline Luxembourg & EURO & 12.89701 & 29.22 & 2.2951 & $\frac{2.2951}{0.2922 \times 12.89701}$ & 0.609021 \\
\hline Hungary & HUF & $7,113.497$ & 19 & 613.522 & $\frac{613.522}{0.19 \times 7,113.497}$ & 0.453930 \\
\hline Malta & EURO & 2.207586 & 35 & 0.5108 & $\frac{0.5108}{0.35 \times 2.207586}$ & 0.661097 \\
\hline Netherlands & EURO & 94.3608 & 25 & 18.43 & $\frac{18.43}{0.25 \times 94.3608}$ & 0.781257 \\
\hline Austria & EURO & 47.05711 & 25 & 7.9394 & $\frac{7.9394}{0.25 \times 47.05711}$ & 0.674874 \\
\hline Poland & PLN & 539.9078 & 19 & 33.104 & $\frac{33.104}{0.19 \times 539.9078}$ & 0.322706 \\
\hline Portugal & EURO & 32.48048 & 21 & 5.6136 & $\frac{5.6136}{0.21 \times .21 .48048}$ & 0.823000 \\
\hline Romania & RON & 177.8497 & 16 & 16.7274 & $\frac{16.7274}{0.16 \times 177.8497}$ & 0.587835 \\
\hline Slovenia & EURO & 1.763751 & 17 & 0.568 & $\frac{0.568}{0.17 \times 1.763751}$ & 1.894358 \\
\hline Slovakia & EURO & 19.67942 & 22 & 2.9453 & $\frac{2.9453}{0.22 \times 19.67942}$ & 0.680291 \\
\hline Finland & EURO & 26.32965 & 20 & 4.547 & $\frac{4.547}{0.20 \times 26.32965}$ & 0.863475 \\
\hline Sweden & SEK & 566.7271 & 22 & 124.096 & $\frac{124.096}{0.22 \times 566.7271}$ & 0.995316 \\
\hline United Kingdom & GBP & 338.9224 & 20 & 43.215 & $\frac{43.215}{0.20 \times 338.9224}$ & 0.637535 \\
\hline
\end{tabular}




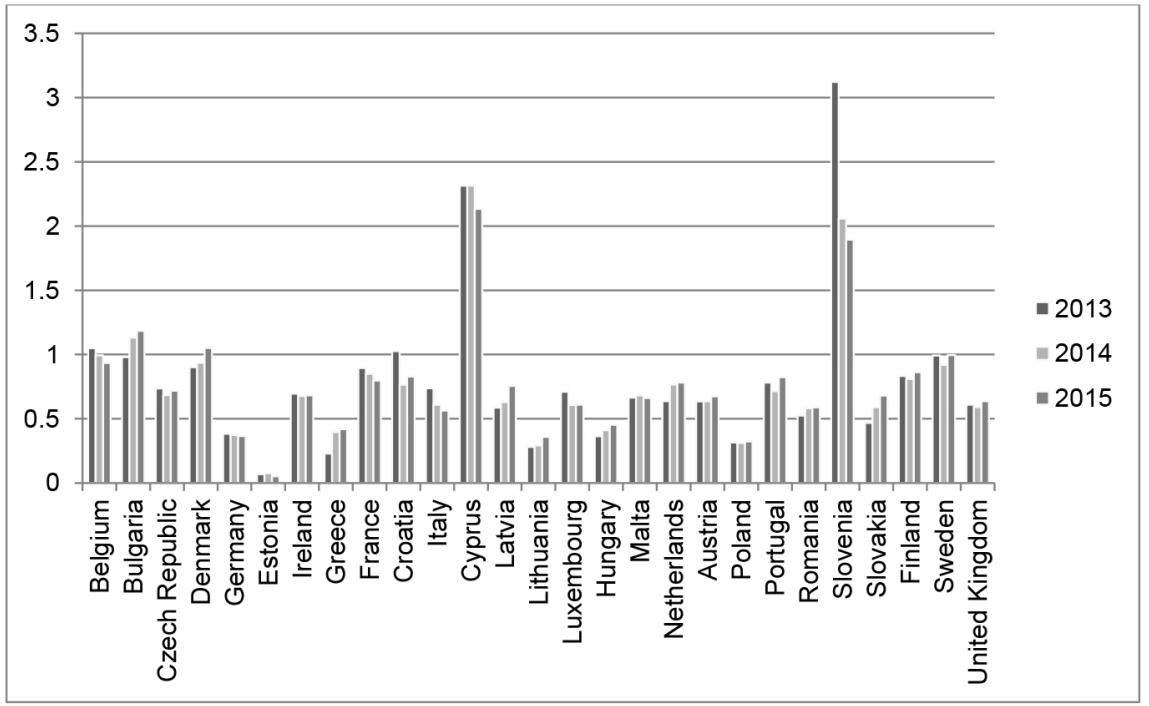

Source: own processing in accordance with AMECO, General Financial Directorate, European Commission, Eurostat

\section{Results}

The EU member states corporate income tax efficiency for the periods 2013-2015 calculated by the first equation can be seen in Fig. 2 .

The Czech Republic's corporate income tax efficiency rate is approximately $70 \%$, which is a very good result in comparison with Germany and Poland that have between 20132015 , approximately $35 \%$. This low number for Germany and Poland could be caused by base erosion and profit shifting.

The corporate income tax efficiency of the particular EU member state is used for the calculation of the weighted average of corporate income tax efficiency rate.

In 2013 the Czech Republic's income tax efficiency rate is approximately $74 \%$, in 2014 it is approximately $68 \%$ and in 2015 it is approximately $72 \%$. The Czech Republic is approaching the EU averagein mentioned period, but does not reach it. Therefore, the null hypothesis $\mathrm{H}_{02}$ is accepted.
With the EU average efficiency, the RWS calculation can be made. Based on the second equation the following results have been calculated (see Tab. 4).

If there was not be a base erosion and profit shifting among the EU member states, the Czech Republic could have the amounts mentioned above as a corporate tax revenue. This hypothetical indicator is compared to the actual amount of corporate tax revenue. The difference can be interpreted as the loss or gain from profit shifting. For a better overview of the results, see Tab. 5 .

As shown in Tab. 5 it is evident that the theoretical corporate tax revenue, which represents revenue without profit shifting (RWS), takes higher value than the actual corporate tax revenue (Rev). It resulted in loss of corporate tax revenue caused by profit shifting. In 2013, the Czech Republic lost CZK 9,404 mil. due to the base erosion and profit shifting. In 2014 the Czech Republic had its 




Source: Authors' own calculation, AMECO, General Financial Directorate, European Commission, Eurostat

\begin{tabular}{c|c|c|c|c|c} 
Tab. 4: & $\begin{array}{l}\text { Calculation of the indicator of revenue without profit shifting } \\
\text { for the Czech Republic for the time periods 2013, 2014, 2015 }\end{array}$ \\
\hline Year & Tax rate (\%) & $\begin{array}{c}\text { Base } \\
\text { (mil. CZK) }\end{array}$ & $\overline{\text { Eff }}$ & RWS calculation & $\begin{array}{c}\text { RWS } \\
\text { (mil. CZK) }\end{array}$ \\
\hline 2013 & 19 & 807,735 & 0.797915 & $0.19 \times 807.735 \times 0.797915$ & 122,456 \\
\hline 2014 & 19 & 948,590 & 0.756025 & $0.19 \times 948.590 \times 0.756025$ & 136,260 \\
\hline 2015 & 19 & $1,013,104$ & 0.771560 & $0.19 \times 1,013.104 \times 0.771560$ & 148,517 \\
\hline
\end{tabular}

Source: Authors' own calculation, AMECO, European Commission

\section{Tab. 5: Calculation of the profit shifting effect (denoted in mil. CZK)}

\begin{tabular}{r|r|r|r}
\multicolumn{1}{c|}{ Year } & \multicolumn{2}{|c|}{ RWS } & \multicolumn{2}{c}{ Rev } & \multicolumn{1}{c}{ RWS-Rev } \\
\hline 2013 & 122,456 & 113,052 & 9,404 \\
\hline 2014 & 136,260 & 123,179 & 13,081 \\
\hline 2015 & 148,517 & 138,140 & 10,377 \\
\hline
\end{tabular}

Source: Authors' own calculation, General Financial Directorate 


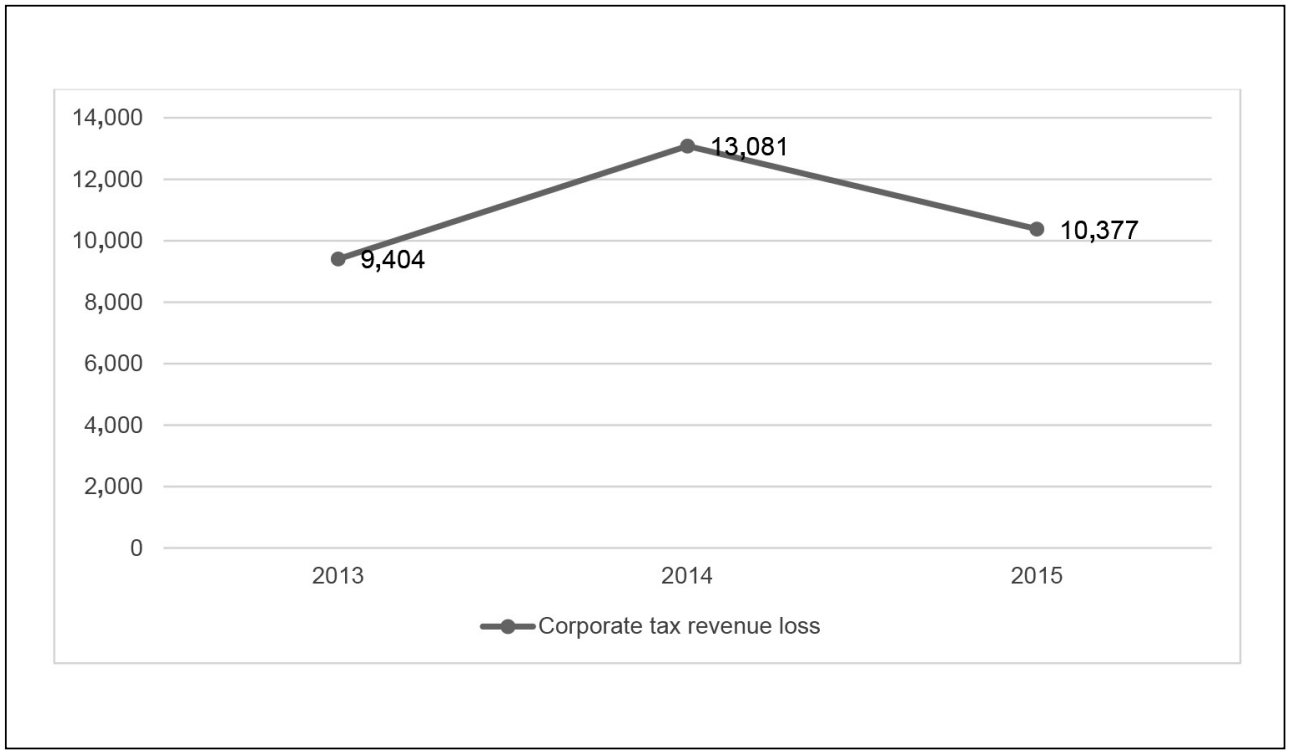

Source: Authors' own calculation

highest tax revenue loss, reaching up CZK 13,081 mil.

The main difference in comparison with the EPRS (2015) research, can be seen from Fig. 1. There is approximately 20 billion CZK difference between Eurostat data and official General Financial Directorate data. In the case of the Czech Republic, ERPS (2015) study resulted in 0.484 billion EURO (approximately 12.5 billion CZK) tax gain in 2013 from based erosion and profit shifting within EU. On the other hand, this paper re-estimated the tax loss with the same methodology except used data. The paper resulted in approximately 9.404 billion CZK tax loss. The null hypotheses $\mathrm{H}_{01}$ and $\mathrm{H}_{03}$ are rejected. And alternative hypotheses are accepted. In Tab. 5 and Fig. 4 it was confirmed that the base erosion and profit shifting cause corporate tax revenue loss in the Czech Republic in the observed period. Also it was confirmed that different data sources may influence final results significantly.

\section{Discussion}

At the very beginning, it is very important to focus on the corporate income tax efficiency rate which is depicted by Figs. 2 and 3. Between 2013 and
2015 the Czech Republic is approaching the EU average. Germany and Poland have one of the lowest efficiency rate, which may be caused by base erosion and profit shifting. Corporate tax gap estimation studies concerning the Czech Republic have a very broad range related to the estimated amount. The estimated amount is located between CZK 57 billion loss and CZK 12.5 billion gain. Author shave observed that the corporate tax revenue loss is approximately CZK 9.404 billion in 2013. These findings are close to UNCTAD (2015) extrapolation for the Czech Republic whose estimation is also CZK 12 billion. IMF (2014) extrapolation estimates the corporate tax gap of 8 billion CZK. Jansky and Cobham (2017) estimate on the IMF (2015) basis, approximately CZK 7 billion. It is the similar methodology that has been used in this paper. The result depends on the input database. For instance, the difference that is shown in the Fig. 1. EPRS (2015) uses for its estimation Eurostat as a database of actual corporate tax revenue. EPRS (2015) study resulted in CZK 12.5 billion gain of corporate tax revenue for the Czech Republic in 2013 due to the profit shifting. On the other hand, authors have changed the Eurostat database to the 
official data of General Financial Directorate on this study. Subsequently, CZK 9.404 billion loss of corporate tax revenue in 2013 for the Czech Republic has been calculated.

Glopolis (2016) brings another point of view. According to its estimation, the Czech Republic can lose up to CZK 57 billion corporate tax revenue caused by base erosion and profit shifting. This figure is obtained from the EPRS (2015) estimation for entire sample i.e. EU 28. The tax loss for entire EU is estimated in amount of EUR 160-190 billion. The amount of CZK 57 billion is calculated from the ration of the Czech Republic's contributions to EU Gross Domestic Product. The authors consider that this is a relatively high number and very rough estimation. From the authors' point of view, the amount of corporate tax revenue that Czech Republic loses is generally between 0 and 20 billion CZK.

There can be another approach. Rohan and Moravec (2017) dealt with the tax information exchange impact on the number of companies relocated and on the amount of foreign direct investments shifted. The profit shifting or the tax avoidance is being widely influenced by agreed instruments on exchange of information. There can be two kinds of taxpayers' reactions.

The first reaction confirms that some companies are interested in anonymity. Rohan and Moravec's (2017) study indicates taxpayers' companies relocation from jurisdictions that are covered by measures of information exchange to the jurisdictions that are not covered by the mechanism of information exchange. These shifted taxpayers may prefer anonymity to tax benefits as they do carry out direct investments into the non-contractual jurisdictions to keep the anonymity and they decided to bear the vindicatory $35 \%$ withholding tax, applied in the Czech Republic for example (see Section 36 subsection 1 letter c) of the Act No. 586/1992 Coll., as amended).

The second detected reaction of taxpayers shows, on the other side, an increase of foreign direct investments at the same moment, the agreements on exchange of information are concluded (or similar measures) with the preferential tax jurisdiction. As when such instruments are concluded the taxation of transactions is targeted by a specific provision and the tax is withheld at the level of $15 \%$ only. The Rohan and Moravec's study (2017) results show that Czech multinational companies, remaining in preferential tax jurisdictions since the anonymity was cancelled, increased the amount of their foreign direct investments, i.e. the remaining companies' owners prefer favorable tax regime instead of anonymity and use the new tax benefit while increasing the amount of direct investments.

The amount of estimated losses due to the tax haven might be considered politically motivated as well (Široký, 2005). The understanding of the offshore issue importance is highly individual from different points of view of different states (Kristofik, Istok, \& Nedelova, 2017). For Germany and Poland the base erosion and profit shifting is a huge problem (e.g. Meyering \& Groene, 2017; Maurer, Port, Roth, \& Walker, 2017; Stolicna \& Cernicka, 2017). However, the Czech Republic is one of the countries being relatively successful in corporate tax collection compared to most countries based on the current study results. Nevertheless, the Czech Republic must follow the OECD and EU and meet the requirements relating to the offshore industry elimination and apply the instruments increasing the intensity of tax information exchange to prevent the base erosion and profit shifting among states, even though the Czech Republic is particularly as a state facing the relatively high VAT gap (CASE, 2015) the issue which influenced the state budget income and seems to be an issue of higher importance from the point of view of the Czech Republic tax administration. The countries with higher political power are more or less the states facing the higher amount of losses due to the base erosion and profit shifting comparing to the countries keeping lower political power as the Czech Republic, which faces the problem of VAT gap particularly, as the studies showed. Such situation results in implementation of huge amount of instruments fighting the tax competition with relatively questionable benefits for some states as the Czech Republic.

\section{Conclusion}

This paper identifies the significant effect of base erosion and profit shifting. The research estimates the corporate tax revenue loss in 2013, 2014 and 2015. In 2013, the corporate tax revenue loss was CZK 9,404 mil. In 2014, the corporate tax revenue loss was CZK 13,081 mil., which was the highest amount in the examined period. Therefore, the null hypothesis $\mathrm{H}_{01}$ was rejected. Studies dealing with a similar issue have different results. For instace, EPRS 
(2015) study resulted in CZK 12.5 billion gain of corporate tax revenue for the Czech Republic in 2013 due to the profit shifting. There is approximately CZK 22 billion difference. According to Glopolis (2016) study, the Czech Republic can lose up to CZK 57 billion corporate tax revenue caused by profit shifting. Glopolis used different methodology, which uses ration of the Czech Republic's contributions to EU Gross Domestic Product, compared to this paper. The results' difference could have been caused by the used methodology or different data source.

The authors are convinced that if official data of a particular EU member state instead of the Eurostat database (see the difference in Fig. 1) was used, there would be totally different results. Thus the null hypothesis $\mathrm{H}_{03}$ was rejected.

From Figs. 2 and 3 there could be seen that the Czech Republic is approaching EU corporate income tax efficiency average but the EU average is still slightly higher than the Czech Republic's income tax efficiency rate. Therefore the null hypothesis $\mathrm{H}_{02}$ was accepted. In comparison with neighboring countries, such as Poland and Germany, which have the lowest corporate income tax efficiency average within $\mathrm{EU}$, the Czech Republic still has sufficient results.

From this research results it is noticeable that corporate tax revenue loss is not such a big issue as the VAT tax gap problem.

This article has been supported by the Internal Granting Agency (IGA) of the FEM CULS Prague, the project No. 20171032 - International Corporate Tax Gap Size Estimation and Profit Shifting Relevant Factors Identification.

\section{References}

Act No. 586/1992 Coll., on Income Taxes, as amended. Retrieved May 7, 2018, from https://www.fulsoft.cz.

Altshuler, R., \& Grubert, H. (2002). Repatriation Taxes, Repatriation Strategies, and Multinational Financial Policy. Journal of Public Economics, 87(1), 73-107. https://dx.doi. org/10.1016/S0047-2727(01)00173-6.

Altshuler, R., \& Grubert, H. (2006). Governments and Multinational Corporations in the Race to the Bottom. Tax Notes, 110(8), 459-474.

Baumann, F., Buchwald, A., Friehe, T., Hottenrott, H., \& Weche, J. (2017). Tax enforcement and corporate profit shifting. Applied Economics Letters, 24(13), 902-905. https:// dx.doi.org/10.1080/13504851.2016.1240331.

Braun, J., \& Weichenrieder, A. (2015). Does Exchange of Information Between TaxAuthorities Influence Multinationals' Use of Tax Havens? [ZEW Discussion Papers 15-015, 39]. ZEW Zentrum für Europäische Wirtschaftsforschung I Center for European Economic Research. Retrieved May 7, 2018, from http://www. econstor.eu/handle/10419/107595.

CASE. (2015). Study to quantify and analyse the VAT Gap in the EU Member States 2015 Report [TAXUD/2013/DE/321]. Retrieved January 7, 2018, from https://ec.europa.eu/ taxation_customs/sites/taxation/files/docs/ body/vat_gap2013.pdf.

Cobham, A., \& Jansky, P. (2017). Global distribution of revenue loss from tax avoidance: Re-estimation and country results [WIDER Working Paper, 55/2017]. Retrieved May 20, 2018, from http://hdl.handle.net/10419/163026.

Crivelli, E., de Mooij, R., \& Keen, M. (2016). Base Erosion, Profit Shifting and Developing Countries. Finanzarchiv: Public Finance Analysis, 72(3), 268-301. https://dx.doi.org/10. 1628/001522116X14646834385460.

Davies, R. B., Martin, J., Parenti, M., \& Toubal, F. (2015). Knocking on Tax Haven's Door: Multinational Firms and Transfer Pricing [SSRN Scholarly Paper, No. ID 2666947]. Rochester, NY: Social Science Research Network. Retrieved October 7, 2017, from http://papers.ssrn.com/abstract=2666947.

Desai, M., Foley, C. F., \& Hines, J. R. (2004). Foreign Direct Investment in a World of Multiple Taxes. Journal of Public Economics, 88(12), 2727-2744. https://dx.doi.org/10.1016/j. jpubeco.2003.08.004.

Desai, M., Foley, C. F., \& Hines, J. R., Jr. (2006). The Demand for Tax Haven Operations. Journal of Public Economics, 90(3), 513-531. https://dx.doi.org/10.1016/j. jpubeco.2005.04.004.

Dharmapala, D., \& Riedel, N. (2013). Earnings Shocks and Tax-Motivated Income-Shifting: Evidence from European Multinationals. Journal of Public Economics, 97(1), 95-107. https://dx.doi.org/10.1016/j. jpubeco.2012.08.004. 
Ebrill, L., Keen, M., Bodin, J.-P., \& Summers, V. (2001). The Modern VAT. Washington: International Monetary Fund.

EPRS. (2015). Bringing transparency, coordination and convergence to corporate tax policies in the European Union: Assessment of the magnitude of aggressive corporate tax planning. Retrieved May 27, 2017, from http://www.europarl.europa.eu/ RegData/etudes/STUD/2015/558773/EPRS_ STU\%282015\%29558773_EN.pdf.

European Commission. (2016). Taxation Trends in the European Union, Data for the EU Member States, Iceland and Norway. https://dx.doi.org/10.2785/751842.

Glopolis. (2016). Výzva politikům: Zaměřte se na daňové ráje! Retrieved October 7 , 2017, from http://glopolis.org/cs/clanky/vyzvapolitikum-zamerte-se-na-danove-raje/.

Gumpert, A., Hines, J. R., \& Schnitzer, M. (2016). Multinational firms and tax havens. Review of Economics and Statistics, 98(4), 713-727. https://dx.doi.org/10.1162/ REST_a_00591.

Hines, J. R. (1999). Lessons from Behavioral Responses to International Taxation. National Tax Journal, 52(2), 305-322.

Hines, J. R. (2014). How Serious Is the Problem of Base Erosion and Profit Shifting? Canadian Tax, 62(2) 443-453.

International Monetary Fund. (2014). Spillovers in International Corporate Taxation [IMF Policy Paper]. Retrieved May 20, 2017, from http://www.imf.org/external/np/pp/eng/2014/ 050914.pdf.

Jansky, P. (2016). Estimating the Costs of International Corporate Tax Avoidance: The Case of the Czech Republic [Working Papers IES, No. 2016/21]. Charles University Prague, Faculty of Social Sciences, Institute of Economic Studies. Retrieved May 14, 2017, from http://econpapers.repec.org/paper/ fauwpaper/wp2016_5f21.htm.

Jansky, P., \& Kokes, O. (2016). Profitshifting from Czech multinational companies to European tax havens. Applied Economics Letters, 23(16), 1130-1133. https://dx.doi.org/ 10.1080/13504851.2015.1137543.

Kristofik, P., Istok, M., \& Nedelova, G. (2017). Motives of Establishing of New Onshore and Offshore Companies by the Slovak Enterprises in 2014. Politická ekonomie, 65(2), 198-216. https://dx.doi.org/10.18267/j.polek.1136.
Lennard, M. (2016). Base Erosion and Profit Shifting and Developing Country Tax Administrations. Intertax, 44(10), 740-745.

Maurer, L., Port, C., Roth, T., \& Walker, J. (2017). A Brave New Post-BEPS World: New Double Tax Treaty Between Germany and Australia Implements BEPS Measures. Intertax, 45(4), 310-321.

Meyering, S., \& Groene, M. (2017). An Analysys of the Assessment of Taxable Earnings in Germany. Journal of Tax Reform, 3(1), 18-28. https://dx.doi.org/10.15826/jtr.2017.3.1.028.

OECD. (2017). Backgroud Brief Inclusive Framework on BEPS. Retrieved January 20, 2018, from https://www.oecd.org/ctp/ background-brief-inclusive-framework-forbeps-implementation.pdf.

OECD. (2015). Mandatory Disclosure Rules, Action 12: 2015 Final Report. https:// dx.doi.org/10.1787/9789264241442-en.

Riedel, N., Zinn, T., \& Hofmann, P. (2015). Do Transfer Pricing Laws Limit International Income Shifting? Evidence from Europe. Retrieved May 14, 2018, from http://www. wiwi.ruhr-unibochum.de/fiwipo/mam/content/ do_transfer_pricing_laws_limit_international_ income_shifting_evidence_from_europe.pdf.

Rohan, J., \& Moravec, L. (2017). Tax Information Exchange Influence on Czech Based Companies' Behavior in Relation to Tax Havens. Acta Universitatis Agriculturae et Silviculturae Mendelianae Brunensis, 65(2), 721-726. https://doi.org/10.11118/ actaun201765020721.

Rohan, J., \& Moravec, L. (2017). Tax Information Exchange Impact on FDI: Tax Havens Czech Case Study. Saint Luis University School of Law Journal. Retrieved May 27, 2018, from http://law.slu.edu/lukasmoravec-jan-rohan.

Stolicna, Z., \& Cernicka, D. (2017). Tax Systems Changes in V4 Countries during Financial Crisis. In Sustainable Economic Growth, Education Excellence and Innovation Management through Vision 2020 (pp. 2546-2551). Vienna: IBIMA.

Široký, J. (2005). The possibility of using corporate profits tax as an economic policy instrument (on the example of effective tax rates in the new EU member states. In Proceedings of the $5^{\text {th }}$ International Conference on Econoic Policy in the New EU (pp. 22-23). Ostrava: VSB. 


\section{Finance}

UNCTAD. (2015). World Investment Report 2015 - Reforming International Investment Governance. Retrieved October 27, 2017, from http://unctad.org/en/PublicationsLibrary/ wir2015_en.pdf.

Zodrow, G. R. (2010). Capital Mobility and Capital Tax Competition. National Tax Journal, 63(4), 865-902. https://dx.doi.org/10.17310/ ntj.2010.4S.03.
Ing. Lukáš Moravec, Ph.D. Czech University of Life Sciences Prague Faculty of Economics and Management Department of Business and Finance

Czech Republic moravec@pef.czu.cz

Ing. Jan Rohan Czech University of Life Sciences Prague Faculty of Economics and Management Department of Business and Finance Czech Republic rohan@pef.czu.cz

Ing. Jana Hinke, Ph.D. University of West Bohemia Faculty of Economics Department of Finance and Accounting Czech Republic hinke@kfu.zcu.cz 


\title{
Abstract
}

\section{ESTIMATION OF INTERNATIONAL TAX PLANNING IMPACT ON CORPORATE TAX GAP IN THE CZECH REPUBLIC}

\author{
Lukáš Moravec, Jan Rohan, Jana Hinke
}

There are many studies focusing on VAT (value added tax) tax gap but very few relevant studies that deal with the corporate income tax loss. The studies vary particularly in their methodology, databases and interpretation. In the case of the Czech Republic the studies resulted in a range between CZK 57 billion tax gap and CZK 12.5 billion corporate tax revenue gain caused by the tax planning. The main aim of the paper is to calculate the corporate income tax efficiency rate for the Czech Republic and compare it with other member states. The indicator of corporate income tax efficiency is important for the calculation of the tax revenue without profit shifting (RWS) indicator and then the subsequent corporate income tax gap estimation for 2013-2015, which is the second goal of the paper. The RWS indicator gives an overview of the Czech Republic's amount of loses/ gains relating to the corporate tax base erosion and corporate profit shifting. In the case when the actual corporate income tax revenue takes a higher value than the revenue without profit shifting indicator the jurisdiction benefits from the profit shifting operations. The opposite situation results in tax revenue losses caused by profit shifting to other "more attractive" tax jurisdictions. Authors' study re-estimation results in approximately CZK 9.404 billion tax gap caused by base erosion and profit shifting instead of 12.5 billion CZK that shows EPRS's study for period 2013. The third aim of the paper is to deal with the difference between input data from Eurostat database and official data from General Financial Directorate.

Key Words: Avoidance, base erosion, profit shifting, revenue, tax, tax loss.

JEL Classification: H21, H26, L51, K34, P52.

DOI: 10.15240/tul/001/2019-1-011 